\title{
Objektivisme en relativisme: \\ Die wetenskap-filosofiese problematiek met betrekking tot historiese Jesus- studies $^{1}$
}

\author{
Riaan Ingram \\ Derpartement Nuwe-Testamentiese Wetenskap \\ Universiteit van Pretoria
}

\begin{abstract}
Objectivism and relativism: Historical Jesus studies with regard to philosophy of science

While many recent historical Jesus studies have been done from theological and methodological viewpoints, this article focuses on the perspective of the philosophy of science. It aims to view some contemporary historical Jesus studies with regard to the philosophy of science from the angle of philosophical hermeneutics inaugurated by Heidegger's reflection on fundamental ontology. The article criticises both an objectivistic view about knowledge that data can be known in ways that correspond to actual objective existence and a relativistic mentality that undermines the value of truth-seeking.
\end{abstract}

\section{INLEIDING}

Historiese Jesus-studies verteenwooordig 'n geskiedwetenskaplike ondersoek. In soverre die geskiedwetenskap 'n onderwerp is van wetenskapsfilosofie (die nadenke oor die fundamentele vooronderstellings van die wetenskap), is historiese Jesus-studies dit dus ook. Die resente gesprekke in die kerk, media en akademie (kyk o a Spangemberg 2004:274-297) maak dit duidelik dat die vraagstuk rondom Jesus as 'n historiese figuur tans baie prominensie geniet. Op akademiese gebied word daar tans 'n groot aantal teologiese en metodologiese perspektiewe op historiese Jesus-studies neergepen, maar daar word selde gevra na die wetenskap-filosofiese fondamente van historiese Jesus-studies.

\footnotetext{
${ }^{1}$ Hierdie artikel is ' $n$ verdere verwerking van Riaan Ingram se M Div-skripsie, voorberei onder leiding van prof dr A G van Aarde, Departement Nuwe-Testamentiese Wetenskap, Fakulteit Teologie, Universiteit van Pretoria (2003).
} 


\title{
Objektivisme en relativisme
}

Hierdie stelling word bevestig deur die doktorale proefskrif van Geyser (1999) ten opsigte van die kontemporêre gesprek rondom historiese Jesus-studies. In Geyser se studie van meer as twee honderd bladsye word heelwat aandag gegee aan teologiese en metodologiese perspektiewe op historiese Jesusstudies, maar slegs agt bladsye word aan die wetenskap-filosofiese perspektief op historiese Jesus-studies afgestaan (kyk Geyser 1999:126-133).

Hierdie artikel is 'n poging om die wetenskap-filosofiese dimensie van historiese Jesus-studies aan die orde te stel. Die doel van die artikel is egter nie om 'n reeds geformuleerde problematiek op te los nie. Laasgenoemde taak kan eers uitgevoer word wanneer die wetenskap-filosofiese problematiek rondom historiese Jesus-studies op die een of ander wyse eksplisiet geformuleer is. Die doel van die artikel is om 'n bydrae in hierdie verband te lewer, deur die wetenskap-filosofiese problematiek van historiese Jesus-studies aan die orde te stel. Dit sal gedoen word in terme van 'n filosofies-hermeneutiese perspektief wat veral deur die vernuwende ontologiese besinning van Heidegger geïnisieer is (Gadamer 2003:254-270; vgl Heidegger 1935:1). Deur verskeie kontemporêre werke wat met betrekking tot die filosofie van die geskiedwetenskap gepubliseer is, in terme van bogenoemde tradisie se kritiek op die Cartesiaanse denkraamwerk aan die orde te stel, word die wetenskap-filosofiese problematiek rondom historiese Jesus-studies op 'n bepaalde wyse gekonseptualiseer.

\section{OBJEKTIVISME, RELATIVISME EN DIE CARTESIAANSE DENKRAAMWERK}

\begin{abstract}
We live in the shadow of a tradition that misleadingly thinks of truth as absolute truth, of truth not just true enough for the time being, but true always and absolutely. Beyond this conception of truth lies a view about knowledge: namely that things can be known in ways that correspond to actual objective existence, and that there is a tight fit between nature and human knowledge. The counterpoint to this tradition, born in reaction to it, is a family of relativisms that reaches its most extreme manifestation in the non-referential views about language, championed by the post-structuralists and associated views, that undermine the value of truth-seeking as an enterprize understood as anything that has much to do with truth.
\end{abstract}

(Bunzl 1997:105)

Gedurende die afgelope dekade is verskillende werke met betrekking tot die filosofie van die geskiedwetenskap gepubliseer wat daarop dui dat die twee perspektiewe wat hierbo deur Bunzl beskryf word, prominensie geniet binne die kontemporêre filosofiese debat oor wat die aard van die geskiedwetenskap is. 
So byvoorbeeld stel Fay (1998:1-11) die wetenskaplike en die retoriese mentaliteit teenoor mekaar. Hy bring die wetenskaplike mentaliteit met objektivisme (“... a view about knowledge: namely that things can be known in ways that correspond to actual objective existence ...") en die retoriese mentaliteit met relativisme (“... views, that undermine the value of truth-seeking as an enterprize understood as anything that has much to do with truth ...") in verband.

Southgate (1996) en Jenkins (1991:59-71) bespreek hierdie opponerende uitgangspunte. Eers beskryf en kritiseer hulle die moderne perspektief op die geskiedwetenskap om dan ten gunste van 'n postmoderne benadering tot die geskiedenis as wetenskap te argumenteer. Bunzl (1997:105111) bring weer die vraag met betrekking tot objektivisme en relativisme in verband met die vraagstuk rondom ontologiese en epistemologiese realisme. Die opposisie tussen objektivisme en relativisme is ook deurlopend 'n prominente tema in Chris Lorenz (1987) se werk oor die teorie van die geskiedenis (kyk Lorenz 1987:57-63, 96-106).

Ook binne kontemporêre Jesus-studies kan hierdie opposisie tussen objektivisme en relativisme gevind word. So kom dit byvoorbeeld ter sprake in Geyser (1999) se proefskrif wat handel oor kontemporêre benaderings tot Jesus-studies. Geyser (1999:126-129) stel die moderne visie op die geskiedwetenskap en die postmoderne kritiek daarop aan die orde. Verder tree hierdie twee opponerende konsepte ook na vore in Dawes (1999) se oorsig van die geskiedenis van historiese Jesus-studies. Dawes se perspektief op die geskiedenis van historiese Jesus-studies kom breedweg daarop neer dat historiese Jesus-studies voor Martin Kähler objektivisties van aard was, terwyl dit onmiddellik na Kähler (1896) relativisties van aard was. Voordat ons objektivisme en relativisme met betrekking tot die kontemporêre besinning rondom die geskiedwetenskap oor die algemeen, en historiese Jesus-studies in besonder, aan die orde stel, is dit eers nodig om hierdie verskynsel as sulks, asook die Cartesiaanse denkraamwerk onderliggend daaraan, te belig.

Heidegger (1935:46) beskuldig Descartes (die vernaamste grondlegger van die moderne filosofiese en wetenskaplike denkraamwerk) daarvan dat hy met die ponering van die beroemde cogito ergo sum, die cogito en die sum ewe primêr stel, maar dan slegs die cogito ondersoek. Die gevolg hiervan is dat moderne filosofiese en wetenskaplike besinning op 'n problematiese ontologiese verstaan van die mens en die wêreld gebaseer is (Heidegger 1935:46; vgl Bernstein 1983:118). Binne die Cartesiaanse denkraamwerk word die syn van syndes op 'n onties-ontologiese wyse verstaan.

"Onties-ontologies" is 'n term wat deur Heidegger (1935:94) gebruik word ter beskrywing van daardie ontologiese perspektief wat sedert Plato binne die 


\title{
Objektivisme en relativisme
}

westerse filosofiese tradisie gehandhaaf word. Hierdie ontologiese beskouing kom daarop neer dat die syn van 'n bepaalde synde verstaan word as die vanselfsprekende teenwoordigheid van daardie synde se dat- en so-syn. Aangesien die syn van 'n bepaalde synde volgens hierdie perspektief nie direk vir ons toeganklik is nie, en aangesien ons daarom slegs oor die syn van 'n bepaalde synde kan dink in terme van die essensie (primêre eienskappe) van daardie synde, word die essensie van 'n bepaalde synde as 'n konseptuele plekhouer vir die syn van daardie synde ingespan (Heidegger 1935:94).

\begin{abstract}
But yet substance cannot be first discovered merely from the fact that it is a thing that exists, for that fact alone is not observed by us. We may, however, easily discover it by means of any one of its attributes because it is a common notion that nothing is possessed of no attributes, properties, or qualities .... It is moreover more easy to know a substance that thinks, or an extended substance, than substance alone, without regarding whether it thinks or is extended.
\end{abstract}

(Descartes 1911b:240, 246)

Hieruit word dit duidelik waarom Descartes die cogito ondersoek, terwyl hy nalaat om ook aan die sum aandag te gee. Die syn van bewussyn is vir Descartes 'n saak wat slegs in terme van die essensie van bewussyn, naamlik: "denkendheid", verstaan kan word.

Naas res cogitans (denkende dinge of bewussyn) onderskei Descartes ook 'n tweede tipe substans, naamlik res extensa (materiële of empiriese dinge) (Descartes 1911b:240; vgl Heidegger 1935:92). Die ontologiese relasie waarbinne bewussyn en empiriese werklikheid met betrekking tot mekaar staan, is volgens Descartes tweërlei van aard. Eerstens, is die bewussyn onuitgebreid in ruimte en tyd, terwyl die empiriese werklikheid wel uitgebreid is in ruimte en tyd (Descartes 1911b:238; vgl Bernstein 1983:115). Die implikasie hiervan is dat bewussyn en empiriese werklikheid in 'n sekere sin van mekaar vervreemd is. Daar is sekere struikelblokke (soos byvoorbeeld die sintuie, oorgelewerde tradisie en vooroordele) wat tussen die bewussyn en die empiriese werklikheid staan, sodat dit in beginsel moontlik is dat die bewussyn die empiriese werklikheid verkeerd kan ken (Descartes 1911b:249-251; vgl Bernstein 1983:117; Gadamer 2003:271). Tweedens, word hierdeur geïmpliseer dat die relasie tussen bewussyn en die empiriese werklikheid epistemologies van aard is. Bewussyn en empiriese werklikheid word op 'n epistemologiese wyse gedefinieer en onderskeidelik subjek en objek genoem. Die subjek is wesenlik dit wat die objek kan en behoort te ken, terwyl die objek wesenlik dit is wat deur die subjek geken kan en behoort te word (Descartes 1911a:191; vgl Bernstein 1983:116-117). Ook hierdie relasie tussen bewussyn en empiriese werklikheid is 
onties-ontologies van aard. Die verband tussen bewussyn en empiriese werklikheid word nie beskryf in terme van hulle syn as sulks nie, maar eerder in terme van hulle onderskeie primêre eienskappe. Dat die bewussyn die empiriese werklikheid kan ken, impliseer dat 'n gedagte in die bewussyn met die essensie van 'n bepaalde empiriese synde kan kongrueer.

Die implikasie van hierdie denkraamwerk is uiteindelik dat die historikus die taak het om die essensie van die vergange werklikheid vir eens en vir altyd te konseptualiseer. By hierdie onties-ontologiese beskouing van bewussyn en empiriese werklikheid pas daar ook 'n bepaalde ontologiese perspektief met betrekking tot taal. Volgens hierdie linguïstiese perspektief is 'n taaluiting 'n semeion (simbool) wat die vermoë het om die essensie van 'n bepaalde synde, soos wat daardie essensie deur 'n gedagte in die bewussyn verteenwoordig word, op 'n volledige en suiwere wyse teenwoordig te stel (Descartes 1911b:252; vgl Gadamer 2003:414; Grondin 1994:33). Taal word hiervolgens dus as proposisioneel van aard beskou, omrede taaluitinge die funksie het om die eienskappe van gedagtes of empiriese syndes te weerspieël. Uiteindelik het die historikus hiervolgens ook die taak om die essensie van die vergange werklikheid in die vorm van 'n kontemporêre teks teenwoordig te stel.

Naas die kapasiteit om empiriese syndes te kan ken, beskik die subjek volgens Descartes ook oor die kapasiteit om keuses te kan maak met betrekking tot dit wat geken word (Descartes 1911b:232; vgl Bernstein 1983:116). Ons kapasiteit om te kan ken is volgens Descartes net so suiwer en perfek soos God se vermoë om te kan ken, sodat ons kennis van objekte in beginsel perfek kan wees - dit is, met die objekte in sigself kan kongrueer. Die enigste tekortkoming van ons kenvermoë is dat dit eindig is. Anders as die oneindige God kan die menslike subjek nooit alles ken nie, maar dit beteken egter nie dat ons dit wat ons wel ken, net onvolmaak kan ken nie (Descartes 1911b:232-233). Ons maak volgens Descartes slegs foute wanneer ons keuses maak op grond van dit wat ons nie op 'n bepaalde moment ten volle ken nie (Descartes 1911b:236; vgl Bernstein 1983:116; Gadamer 1985:262). Ons kan tot volmaakte kennis van die essensie van sake kom, maar ons kan ons soms ook misgis deur leuens vir die waarheid aan te sien. Daarom moet ons altyd die nodige stappe neem om te verseker dat ons kennis volmaak daar uitsien.

Eerstens moet die subjek alle vooroordele (soos byvoorbeeld vooroordele wat deur tradisie oorgelewer word) ter syde stel of ophef, ten einde seker te maak dat objekte in sigself geken word (Descartes 1911b:252-253; vgl Bernstein 1983:116; Gadamer 1985:262). Tweedens is die enigste kriteria waarvolgens kennis beoordeel en gefundeer behoort te word, die rasionaliteit waaroor alle mense beskik (Bernstein 1983:117; vgl Gadamer 1985:257). Alle "kennis" wat deur tradisie of empiriese waarneming bekom word, moet volgens 


\section{Objektivisme en relativisme}

rasionele kriteria geweeg en beoordeel word, ten einde te verseker dat hierdie kennis op 'n legitieme wyse (in die objekte self) gefundeerd is. Descartes beskou die rasionaliteit waaroor die subjek beskik, as universeel en absoluut. Universeel, deurdat dieselfde rasionaliteit op alle tye en plekke vir alle subjekte dieselfde is. Hierdie rasionaliteit is in der waarheid a-histories van aard (Bernstein 1983:117). Absoluut, deurdat hierdie rasionaliteit die enigste middel is waardeur suiwere kennis van die objekte in sigself bekom kan word, en waardeur onsekerheid en foute met betrekking tot waarheidsoordele uitgeskakel kan word (Bernstein 1983:117; vgl Gadamer 1985:259-260).

Objektivistiese en relativistiese denke ontstaan wanneer daar op hierdie wyse tussen 'n kennende subjek en gekende objek onderskeid getref word. Dit ontstaan veral wanneer die ideaal van die relasie tussen subjek en objek daaruit bestaan dat die subjek tot suiwere en legitieme kennis van die essensie van die objek in sigself moet kom. Objektivisme behels die optimistiese perspektief op die vermoë van die subjek om die objek in sigself en seker te ken. Relativisme behels die pessimistiese perspektief op die kenvermoë van die subjek (vgl Bernstein 1983:8). Die perspektief van 'n subjek-objek digotomie, en die perspektief van 'n epistemologiese relasie tussen subjek en objek, is dus voorwaardes vir beide objektivisme en relativisme. Hierdie ontologiese perspektief wat op die essensie van sake fokus, het op twee verskillende wyses ernstige implikasies vir historiese navorsing. Enersyds, in soverre menslike bewussyn die agent van historiese navorsing is, het die Cartesiaanse ontologiese beskouing van die relasie tussen bewussyn en empiriese werklikheid implikasies vir die wyse waarop daar oor die aard van die geskiedwetenskap gedink word. Andersyds, in soverre die mens die objek van die geskiedwetenskap is, het hierdie ontologiese beskouing ook implikasies vir die wyse waaroor daar oor die doel en eindproduk van die geskiedwetenskap gedink word. Vervolgens stel ek hierdie implikasies aan die orde in soverre dit in die vorm van objektivisme en relativisme met betrekking tot die geskiedwetenskap na vore tree.

\section{OBJEKTIVISME IN DIE GESKIEDWETENSKAP EN HISTORIESE JESUS-STUDIES}

Binne die geskiedwetenskap is die objektivistiese vooronderstelling dat die brug tussen subjek en objek oorgesteek kan word. Hierdie oorskreiding veronderstel die ideaal dat die historikus die vergange werklikheid in essensie behoort te ken. Dit is 'n ideaal wat veral binne die historiese positivisme nagestreef en geglo moontlik is. Volgens hierdie perspektief sou die historikus daartoe in staat wees om gebeure uit die vergange werklikheid te ken, soos wat daardie gebeure in sigself daar uitgesien het (Southgate 1996:22; vgl Lorenz 1987:20; Dreyer 
1974:48; Geyser 1999:126-127). Hierdie uitgangspunt kan byvoorbeeld in Ernst Troeltsch se drie metodologiese beginsels van kritiek, analogie en korrelasie onderskei word.

Troeltsch se beginsel van kritiek kom daarop neer dat die dokumente wat van Jesus se lewe getuig, op 'n kritiese wyse deur die historikus benader moet word, omrede hierdie getuienis nie objektief en neutraal is nie, maar die vooroordele en waardes van hulle skrywers weerspieël (Dawes 1999:28; vgl Via 2002:31). Die getuienis aangaande Jesus se lewe word as 'n hindernis beskou wat die subjek se weg na die objek blokkeer. Deur die kritiese toepassing van die rede sou hierdie hindernis egter oorkom kon word. Hierdie manier van dink kan ook in die werk van Reimarus gesien word. Volgens Reimarus is aan die evangelies vorm gegee volgens die oortuigings en waardes van latere Christene, sodat die ware gebeure van Jesus se lewe - soos wat laasgenoemde in sigself daar uitgesien het - nie daardeur weerspieël word nie (Dawes 1999:56). Tog was Reimarus daarvan oortuig dat die waarheid aangaande Jesus se lewe wel ontdek sou kon word, indien daar krities met die evangelies, wat daarvan getuig, omgegaan word (Dawes 1999:55). Die vooronderstelling wat duidelik hier agter lê, is dat die historikus (as subjek van historiese navorsing) daartoe in staat is om die vergange werklikheid (as objek van historiese navorsing) te ken, soos wat laasgenoemde in sigself daar uitgesien het.

Troeltsch se metodologiese beginsel van analogie sluit by sy beginsel van kritiek aan, en behels dat die ware gebeure van Jesus se lewe slegs ontdek kan word wanneer ons aanneem dat laasgenoemde soortgelyk was aan gebeure in die hede (Dawes 1999:28). Aangesien die rasionaliteit van die mens universeel en a-histories van aard is, is dit moontlik om met behulp van die rede vir eens en vir altyd vas te stel watter gebeure moontlik is en watter nie. Dit wat volgens die wetenskap in die hede as moontlik geag word, word dan as kriteria gebruik om die hindernis van die verdoeselende interpretasies van die vroeë Christene te oorkom. So het Strauss die evangelies nie as geskiedenis beskou nie, maar as mite (Dawes 1999:87; vgl Craffert 2001:14). Die weergawe van Jesus se lewe in die evangelies is volgens hom problematies, omdat hierdie getuienis deur die mitologiese wêreldbeeld van die vroeë Christene vervorm is. Daarom is dit vir die historikus nodig om die mitiese kleed van die evangelies af te werp, ten einde 'n ware beeld van Jesus te kry (Dawes 1999:89). Dit wat in die hede as moontlik geag word, word dan as kriteria gebruik om die twyfelagtige momente in die evangelies te elimineer. Die vooronderstelling wat duidelik hier agter lê, is dat die werklikheid essensieel dieselfde behoort te wees in die verlede as in die hede. 


\section{Objektivisme en relativisme}

Die historiese positivisme het ook veronderstel dat die samehang tussen bepaalde gebeure in die vergange werklikheid - soos wat dit in sigself daar uitgesien het - deur die historikus geken sou kon word. Soos in die natuurwetenskappe, is die samehang tussen verskillende gebeure beskou as kousaal van aard. 'n Bepaalde gebeure sou hiervolgens slegs deeglik verstaan kon word wanneer die oorsake en gevolge daarvan vasgestel is (Southgate 1996:21; vgl Lorenz 1987:58-59). Anders gestel: Indien die struktuur of samehang van die reële werklikheid kousaal van aard is, dan moet kennis wat met die reële werklikheid in sigself kongrueer, ook kennis van gebeure wees wat op 'n kousale wyse met mekaar saamhang.

Troeltsch se metodologiese beginsel van korrelasie stem ooreen met die objektivistiese vooronderstelling dat alle gebeure op 'n kousale wyse met mekaar saamhang. Die gebeure van Jesus se lewe sou slegs verstaan en verklaar kon word, wanneer die verband tussen laasgenoemde en ander gebeure in dieselfde konteks, deeglik aangetoon en verduidelik kon word (Dawes 1999:28; vgl Via 2002:31-32).

Die veronderstelling van Aristoteles in verband met die geskiedwetenskap, naamlik dat daar op 'n absolute wyse tussen hede en verlede onderskei kan en behoort te word, kan steeds by die objektivistiese beskouing van die geskiedenis onderskei word (kyk Southgate 1996:22-23, 109110). Volgens die objektivisme moet historici hulleself van hulle eie vooroordele in die hede distansieer wanneer hulle die verlede bestudeer. Die bedoeling is dat hulle dit wat van die verlede getuig, neutraal en objektief moet ondersoek. Die uitdagings van die hede mag hoegenaamd nie die uiteindelike beeld van die verlede wat op hierdie manier bekom word, beïnvloed nie. Die vooroordele van die historikus in die hede moet as 't ware opsy geplaas word, sodat die vergange werklikheid objektief en in sigself geken kan word (Southgate 1996:17-18; vgl Bernstein 1983:116).

Hierdie onderskeid tussen hede en verlede impliseer ook 'n skerp onderskeid tussen feite en waardes (Southgate 1996:114; vgl Romm 1987:184; Dreyer 1974:47). Die vernaamste onderskeid tussen feite en waardes sou daarin bestaan dat feite objektief en waardes subjektief is. Omrede feite die stand van sake in die reële werklikheid weerspieël, behoort dit vir alle rasionele waarnemers geldig te wees. Waardes weerspieël hiervolgens egter die stand van sake volgens die sentiment van 'n individu of 'n groep, en hoef dus nie vir alle rasionele wesens geldig te wees nie. Volgens die historiese positivisme mag historici geen waarde-oordele oor dit wat in die verlede gebeur het, maak nie. Hulle behoort eerder die objektiewe feite bloot vir sigself laat spreek. Dit wil sê, neutrale empiriese waarnemings móét gemaak word en op grond van universele rasionele kriteria móét die verlede gerekonstrueer word. So mag die 
historiese Jesus-navorser, byvoorbeeld volgens William Wrede (kyk Via 2002:31), nie beïnvloed word deur belange of standpunte (soos byvoorbeeld deur die oortuigings en belange van die kerk) in die hede nie, maar behoort objektiwiteit ten alle koste bewaar te word.

Die objektivistiese epistemologie het dan ook tot 'n bepaalde beskouing van kennis binne die geskiedwetenskap aanleiding gegee, naamlik dat kennis altyd feitlik van aard is. Feite is beskou as linguïstiese konstruksies wat bepaalde aspekte van die reële werklikheid weerspieël, soos wat daardie aspekte in sigself (onbeïnvloed deur die ondersoeker) daar uitsien (Romm 1987:184). Aangesien die gebeure van die vergange werklikheid, asook die onderlinge samehang tussen hierdie gebeure, hiervolgens geken en in die vorm van feitlike linguïstiese rekonstruksies weergegee sou kon word, sou dit in beginsel ook moontlik wees dat hierdie feitlike linguïstiese rekonstruksies van die vergange werklikheid, die vergange werklikheid teenwoordig sou kon stel in die hede (Southgate 1996:24; vgl Dreyer 1974:48-49). Daar word dus veronderstel dat die vergange werklikheid bestaan uit 'n aantal samehangende gebeure en dat hierdie gebeure (asook hulle onderlinge samehang) op so 'n wyse deur die geskiedwetenskap geken en verstaan sou kon word, dat historici se linguïstiese rekonstruksies van hierdie gebeure met die wese en betekenis van daardie gebeure in sigself sou kon kongrueer.

Sodanige kennis en linguïstiese rekonstruksies van die verlede kon in beginsel objektief wees in soverre dit 'n weergawe van die vergange werklikheid in sigself was. Dit kon ook finaal wees in soverre geen ander weergawe van die verlede, as juis so 'n objektiewe weergawe daarvan, legitiem sou kon wees nie (Southgate 1996:24).

Die navorser in die hede het hiervolgens dus geen invloed op die resultaat van historiese navorsing nie. Slegs die reële vergange werklikheid in sigself sou deur die produkte van historiese navorsing weerspieël word. Die motivering vir die beoefening van die geskiedwetenskap was dus eenvoudig die feit dat die waarheid aangaande die vergange werklikheid sodoende vertel sou kon word. Daar is geglo dat wanneer die waarheid aangaande die vergange werklikheid bekend gemaak word, dit mense in die hede sal vrymaak van die las van allerhande wanopvattings en onderdrukkende ekonomiese, sosiale en politieke strukture (Southgate 1996:56-57; vgl Via 2002:31-32). So wou Strauss ons byvoorbeeld vrymaak van die mitologiese beskouing oor Jesus se lewe, wat volgens hom deur die primitiewe interpretasies van die dissipels vir ons daargestel is. Dit wou hy doen deur die waarheid aangaande Jesus se lewe bekend te maak (Dawes 1999:89). Ten einde die moderne mens vry te maak van die wanopvattings van die kerk, wou Ritschl weer aantoon hoe die ware visie en doel van Jesus se lewe eintlik daaroor gegaan het om 'n nuwe moraliteit 


\section{Objektivisme en relativisme}

aan ons bekend te stel (Dawes 1999:153). Volgens die historiese positivisme was die historikus, as subjek van historiese navorsing, daartoe in staat om die vergange werklikheid te ken soos wat dit in sigself was. Die historikus is in staat om vergange werklikheid te verklaar en weer te gee in die vorm van tekste wat met die vergange werklikheid in sigself kongrueer. Daarom kon die motivering van hierdie epistemologiese benadering eenvoudig die strewe na die waarheid aangaande die verlede wees.

Tydens die afgelope paar dekades het insigte op verskillende wetenskaplike terreine na vore gekom wat hierdie beskouing van die geskiedwetenskap onaanvaarbaar gemaak het. Hierdie insigte het aangetoon dat geen mens (ook nie die historikus nie) tot kennis van die reële werklikheid in sigself kan kom nie, maar dat alle menslike kennis deur eindige, kontekstuele, subjektiewe en linguïstiese faktore bepaal word. Die ideaal van die objektivisme, naamlik om die gaping tussen subjek (historikus) en objek (vergange werklikheid) te oorkom, ten einde kennis daar te stel wat met die vergange werklikheid in sigself kongrueer, is hiermee tot niet.

\section{PROBLEME MET OBJEKTIVISME}

\subsection{Psigologiese kritiek}

Tydens die afgelope paar dekades het die sielkunde ons geleer dat mense selektief waarneem (Southgate 1996:59; vgl Weiten 2001:25). Elke dag word ons sintuie gekonfronteer met meer data as wat ons in staat is om te verdiskonteer. Daarom selekteer ons sekere aspekte uit die magdom van potensiële ervarings wat die lewe aan ons bied, terwyl ons ander ignoreer. So byvoorbeeld is daar tydens die Tweede Wêreldoorlog gevind dat moeders gewoonlik ongestoord voort sou slaap gedurende 'n bomaanval, maar dat hulle te midde van so 'n aanval skielik sou wakkerskrik wanneer hulle babas begin huil (Southgate 1996:60). Wanneer daar dan gevra word na die kriteria waarvolgens ons ons ervarings selekteer, toon psigologiese studies dat ons deur die gebruik van ons sintuie sedert geboorte vir onsself betekenisvolle interpretasieraamwerke van die data wat ons ervaar, opbou. En, dat ons dan gedurende die res van ons lewens volgens hierdie interpretasieraamwerke voortgaan om uit die magdom van potensiële data te selekteer (Southgate 1996:61; vgl Lorenz 1987:25-28; vgl Weiten 2001:25). Hierdie interpretasieraamwerke word grootliks deur die aard van ons kulturele en sosiale konteks beïnvloed (Southgate 1996:61; vgl Gadamer 2003:389-390). Dit beteken dat die waarnemings wat ons daarvolgens maak, nie net die aard van die werklikheid weerspieël nie, maar ook die waardes van die spesifieke kultuurgroep en sosiale klas waaraan ons behoort. 
Enersyds impliseer bogenoemde psigologiese insigte dat ons waarneming en ervaring van die werklikheid selektief is, en dus nooit volkome kan kongrueer met die objektiewe stand van sake in die reële werklikheid nie. Andersyds impliseer dit dat die kulturele en sosiale konteks waarbinne ons lewe, 'n konstituerende rol speel in die wyse waarop ons die werklikheid rondom ons ervaar, interpreteer en uiteindelik verstaan. Dit is dus vir ons onmoontlik om die werklikheid objektief en neutraal te ken en te verstaan. Ons is nie passiewe en neutrale waarnemers van 'n objektiewe werklikheid nie, maar speel altyd 'n konstituerende rol in dit wat ons uiteindelik as die werklikheid beskou. Dit wat ons uiteindelik as die werklikheid ervaar en verstaan, is dus nie objektiewe weerspieëlings daarvan nie. Ons ervarings en interpretasies van die werklikheid word eerder deur ons kulturele en sosiale waardes beïnvloed en gekonstitueer.

Soos ons hierbo gesien het, impliseer die basiese veronderstelling van die objektivistiese historiese wetenskap (naamlik dat die historikus die vergange werklikheid finaal en objektief kan ken soos wat laasgenoemde in sigself daar uitsien) 'n drastiese onderskeid tussen hede en verlede, asook tussen feite en waardes. Bogenoemde psigologiese insigte ondermyn egter beide hierdie uitgangspunte. Wanneer ons leer dat die kulturele en sosiale waardes 'n konstituerende rol speel in die wyse waarop ons die werklikheid ervaar en verstaan, word dit onmoontlik om hierdie onderskeid tussen feite en waardes, hede en verlede, te handhaaf.

Bogenoemde insigte impliseer dat die waardes van die bepaalde kulturele of sosiale groep waaraan ons behoort, altyd 'n bepalende rol speel in dit wat ons uiteindelik as die werklikheid ervaar. Hiermee word alle waardevrye waarneming dan onmoontlik, sodat die tradisionele onderskeid tussen feite en waardes verkrummel. Die historikus is geen neutrale waarnemer wat die vergange werklikheid kan ken soos wat dit in sigself daar uitsien nie. Historici kyk eerder na die empiriese gegewens wat van die vergange werklikheid getuig, deur die bril van die waarde- of interpretasiesisteem van die groep waaraan hulle behoort. Op hierdie manier word die posisie van 'n historikus in die hede ook outomaties by sy of haar bestudering en interpretasie van die empiriese getuienis aangaande die vergange werklikheid betrek. Hiermee blyk die ideaal dat die historikus die vergange werklikheid kan ken en verstaan, soos wat laasgenoemde in sigself was, 'n onmoontlikheid te wees.

\subsection{Linguïstiese kritiek}

Tydens die afgelope paar dekades het ook die sogenaamde linguïstiese keerpunt plaasgevind. Laasgenoemde behels die besef dat taal nie net 'n 


\section{Objektivisme en relativisme}

reflektiewe waarde het nie, maar dat dit ook 'n konstituerende waarde het (Southgate 1996:72-73; vgl Fay et al 1998:3). Gevolglik kan taal nie meer as 'n helder skoon venster beskou word waardeur ons ongestoord na die werklikheid waarna dit verwys, kan kyk nie. Daar is besef dat taal eerder soos 'n gevlekte ruit is. Dit werk konstituerend in op dit wat ons uiteindelik daardeur sien. Daar is besef dat linguïstiese uitinge in 'n sekere mate outonome strukture is wat in geen suiwer reflekterende verband met die werklikheid daarbuite staan nie. Verder is ook besef dat 'n bepaalde taaluiting ook nie volledig die bedoeling daarvan kommunikeer nie, maar dat dit ook betekenis kry in terme van dit wat dit voorafgaan en dit wat daarop volg (Gadamer 2003:378; vgl Grondin 1994:37-38). Die betekenis van 'n bepaalde taaluiting of teks word dus nie net bepaal deur die saak waarna dit in die reële werklikheid verwys nie, maar ook deur die verband waarin dit met ander woorde, frases, vrae en antwoorde staan. En, die betekenis van 'n bepaalde taaluiting of teks word weer bepaal deur die geheel wat verskillende elemente daarbinne en daarbuite in verband met mekaar vorm (Southgate 1996:72; vgl Gadamer 2003:383).

Verder is ook besef dat die waardes en wêreldbeskouing van 'n bepaalde taalgroep in die woordeskat van daardie taalgroep weerspieël word. Die betekenisse wat bepaalde woorde en frases tot ' $n$ teks of taaluiting bydra, is dus ook nie suiwere weerspieëlings van die werklikheid in sigself nie, maar eersgenoemde werk self ook vormend en betekenisgewend in op dit waarna verwys word (Southgate 1996:72-73; vgl Gadamer 2003:396).

Wanneer hierdie konstituerende waarde van taal in berekening gebring word, kan die mate waarin ' $n$ bepaalde teks met die stand van sake in die reële werklikheid ooreenstem, nie meer die enigste kriterium wees waarvolgens die waarde van daardie teks beoordeel word nie. Omrede representasie nie meer die enigste funksie van taal blyk te wees nie, speel die wyse waarop ' $n$ taaluiting of teks aanmekaar gesit is, ook ' $n$ rol in die betekenis wat daardie taaluiting of teks uiteindelik sal hê (Southgate 1996:7475; vgl Fay et al 1998:3-4). Gevolglik behoort ' $n$ mens te vra na die rede waarom ' $n$ teks op ' $n$ bepaalde manier aanmekaar gesit is, ten einde die bepaalde betekenis te hê wat dit wel het. En, omdat hierdie rede nie uitsluitlik in die teks se refleksie van die reële werklikheid gevind kan word nie, kom ideologiese aspekte ook ter sake (Southgate 1996:74-75; vgl Rom 1987:184).

Wanneer dit nie meer net die objektiewe werklikheid is wat die struktuur en betekenis van 'n teks bepaal nie, word dit noodsaaklik dat dit wat historici deur ' $n$ bepaalde linguïstiese konstruksie van die werklikheid wil bereik, in ag geneem word. Die doelwit of ideologie van historici is medebepalend van die struktuur en uiteindelik ook die betekenis van die 
tekste wat hulle produseer. Verder speel die wêreldbeeld van die taalgroep waaraan 'n historikus behoort, ook 'n rol in die uiteindelike betekenis van die teks wat hy of sy skryf, omrede die taal waarin hy of sy skryf, die wêreldbeeld van sy of haar taalgroep weerspieël (Gadamer 2003:396-397). Aangesien ideologiese en wêreldbeskoulike aspekte in tekste weerspieël word, word dit onmoontlik om 'n linguïstiese representasie daar te stel wat met die werklikheid in sigself sal kongrueer. Wanneer hierdie insig binne die geskiedwetenskap van toepassing gemaak word, word die objektivistiese ideaal om die vergange werklikheid te rekonstrueer, soos wat dit in sigself was, onmoontlik (Southgate 1996:76; vgl Gadamer 2003:397).

\subsection{Die uniekheid van geskiedenis as wetenskap}

In soverre geskiedenis wetenskap is, fokus die historikus op 'n bepaalde objek van studie. In soverre die geskiedwetenskap as geesteswetenskap bedryf word, is die voorwerp van historiese studie die vergange werklikheid van die mens. In die geesteswetenskappe is die geskiedwetenskap uniek in die opsig dat die voorwerp van studie nie direk vir die historikus toeganklik is nie (Dreyer 1974:24; vgl Lorenz 1987:284). Die verlede is vir eens en vir altyd verby, en die historikus kan nie eksperimente opstel ten einde die resultate van vorige navorsing en teenswoordige hipoteses te toets nie. Die historikus het slegs indirekte toegang tot die "ware objek" van studie en moet deurgaans van empiriese objekte, soos monumente en dokumente wat van die vergange werklikheid getuig, gebruik maak ten einde ' $n$ blik op die eintlike objek te kry (Dreyer 1974:25; vgl Lorenz 1987:284).

Die probleem wat veroorsaak word deurdat die historikus die eintlike objek slegs op ' $n$ indirekte manier kan benader, behels nie net die afwesigheid van empiriese getuienis aangaande alle gebeure in die verlede nie. Dit behels ook dat die meeste van die getuienis wat wel bestaan, soos monumente en dokumente, in die vorm van taal deur mense daargestel is. Hierdie getuienis van die verlede is beïnvloed deur die kulturele en sosiale waardes en belange in die linguïstiese en wêreldbeskoulike raamwerke van ons voorgeslagte. Dit is daarom nie objektiewe weerspieëlings van die vergange werklikheid in sigself nie.

Hierdie probleem is reeds vroeg raakgesien. As oplossing vir die probleem moes historici, deur op hulle rasionele vermoë staat te maak, die betroubare en onbetroubare elemente in die bronne van mekaar onderskei. Deur die toepassing van die korrekte "kritiese metode" of "rasionele standaard" sou die historikus die koring van die kaf kon skei (Southgate 1996:27; vgl Lorenz 1990:25-28). In hierdie verband het ons reeds as voorbeelde verwys na die beginsels van Troeltsch en die werk van verskeie 
historiese Jesus-navorsers (kyk Dawes 1999:28, 87-89; vgl Craffert 2001:1317).

Die probleem met hierdie oplossing is dat geen mens kontekstueel ongebonde en waardevrye oordele kan vel nie, omrede menslike verstaan en interpretasie geskied in terme van die een of ander kultureel- en sosiaalgebonde interpretasieraamwerk, soos deur die linguïstiese en psigologiese kritiek vir ons duidelik gemaak is. Die "rasionele standaarde" of "kritiese metodes" blyk eerder waardebelaaide weerspieëlings van historici se eie kulturele en sosiale situasies te wees (Southgate 1996:82). Lorenz (1987:285) voer aan dat die praktyk van die geskiedwetenskaplike dissipline daarop dui dat dit onmoontlik is om tot absolute en finale waarhede aangaande die verlede te kom. Historici kom in die praktyk eerder tot verskillende konstruksies van die vergange werklikheid. Southgate (1996:88105) dui ook aan hoe die werk van historici uit feministiese, Marxistiese en postkoloniale kringe (kyk Van Aarde 2004:1105-1125) tydens die afgelope paar dekades daarop gewys het dat geskiedenis dikwels met ideologiese motiewe geskryf word.

\section{RELATIVISME IN DIE GESKIEDWETENSKAP EN HISTORIESE JESUS-STUDIES}

Die probleme met historiese positivisme het belangrike implikasies vir ons verstaan van die geskiedwetenskap gehad. Die insig dat historici geen toegang tot die vergange werklikheid in sigself het nie, laat die vraag ontstaan of hulle hoegenaamd enige toegang tot 'n reële vergange werklikheid het. Is daar enige verskil tussen die resultate van historiese navorsing en fiksie, indien die vergange werklikheid nie suiwer en getrou deur tekste weerspieël kan word nie? Verder impliseer die verskynsel dat objektiewe kennis en begrip van die vergange werklikheid nie moontlik is nie, weer dat suiwere belangstelling in die verlede ter wille van die waarheid van die verlede, nie die motivering vir historiese navorsing kan wees nie. Allerhande kulturele, ideologiese en ander faktore wat verband hou met die subjek van historiese navorsing in die hede, moet nou in gedagte gehou word. Die optimisme van die objektivisme oor die vermoë van die subjek om die objek te ken, is in sommige kringe vervang deur relativisme se pessimisme in hierdie verband. Geen kennis aangaande die vergange werklikheid sou hiervolgens moontlik wees nie, sodat historiese navorsing tot 'n futiele of ideologiese bedryf gereduseer word (Fay 1998:8; vgl Geyser 1999:127-129).

Soos ons gesien het, behels relativisme volgens Bernstein die beskouing dat die gaping tussen subjek en objek nie oorgesteek kan word nie. Ons kennis kan nooit die reële werklikheid in sigself weerspieël nie, maar is eerder relatief 
tot die kulturele, sosiale en wêreldbeskoulike raamwerk van die subjek. Dink aan die empiriese getuienis aangaande die vergange werklikheid, soos dokumente en monumente, as die data waarop die geskiedwetenskap fokus. En, dink aan historici se rekonstruksies van die verlede as die teorieë waarmee hulle die data verklaar. Objektivisme sou dan die beskouing behels dat die empiriese data op so 'n manier vormend inwerk op die historiese teorieë, dat die teorieë getroue weerspieëlings van die vergange werklikheid is. Anders gestel: Volgens die objektivisme werk empiriese data vormend in op die teorieë wat dit verklaar, en nie omgekeerd nie (Bunzl 1997:108; vgl Bernstein 1983:8). Tog voer sekere geleerdes (kyk Bunzl 1997:109) aan dat daar nie empiriese data bestaan waarvolgens op hierdie manier tussen verskillende teorieë bemiddel kan word nie. Laasgenoemde beskouing word soms in bepaalde insigte met betrekking tot taal, en soms in bepaalde insigte met betrekking tot empiriese waarneming, gefundeer (Bunzl 1997:109). In die vorige afdeling het ons reeds beide groepe insigte bespreek, maar hier moet ons dit vanuit 'n ander hoek beskou ten einde historiese relativisme te verstaan.

Wanneer die insigte van die linguïstiese keerpunt tot 'n uiterste gevoer word, word die konstituerende waarde van taal op so 'n manier oorbeklemtoon, dat ontken word dat tekste hoegenaamd enige verband met die reële werklikheid het. Daar word voorgehou dat tekste absoluut konstituerend is van die werklikheid wat dit voorgee om te beskryf (Fay 1998:8; vgl Southgate 1996:71-73). Hiervolgens is taal dan eerder soos 'n spieël, waardeur ons geen uitsig - nie eens 'n gevlekte en belemmerende blik - op 'n reële werklikheid het nie, maar waarin ons slegs ons eie vooroordele kan sien. Die teorieë wat historici aanbied ter verklaring van die empiriese data, is hiervolgens linguïstiese konstruksies wat aan die empiriese data vorm en betekenis gee. Volgens die relativisme het die empiriese data geen vorm of betekenis voordat dit nie deur sodanige linguïstiese konstruksies gevorm en betekenisvol gemaak is nie. Met ander woorde: Data word gevorm deur teorieë, en nie omgekeerd nie.

Dieselfde beskouing kan ook op grond van die aard van empiriese waarneming gehandhaaf word (Bunzl 1997:109; vgl Southgate 1996:60-62). Soos ons reeds gesien het, het die psigologie die insig opgelewer dat menslike waarneming altyd selektief en waardebelaai is. Ons maak nooit neutrale empiriese waarnemings nie, maar ons waarnemings word altyd gevorm deur ons interpretasieraamwerke, terwyl laasgenoemde weer deeglik beïnvloed word deur die waardes van die kulturele of sosiale groepering waarin ons onsself bevind.

Op grond van hierdie insigte en argumente kom historiese relativiste dan tot die gevolgtrekking dat data deur teorieë gevorm word, en dat data dus nie onafhanklik van teorieë betekenis het nie (Bunzl 1997:108). 'n Bepaalde teorie 


\section{Objektivisme en relativisme}

skep spesifieke sinvolle feite uit die beskikbare data ter ondersteuning van daardie teorie se aansprake. Daarom kan dieselfde data hiervolgens verskillende teorieë fundeer, sonder dat dit moontlik is om op grond van die data te diskrimineer tussen die verskillende teorieë. Die resultaat van historiese navorsing is hiervolgens nie rekonstruksies van die vergange werklikheid op grond van die empiriese data wat van daardie werklikheid getuig nie. Dit is eerder linguïstiese konstruksies waarvolgens die beskikbare data gevorm word. Hierdie konstruksies weerspieël die belange en waardes van 'n historikus of die groep waarbinne hy of sy beweeg.

So byvoorbeeld, voer sommige historici aan dat die produk van historiese navorsing geen spieëlbeeld van die vergange werklikheid is nie, maar dat dit eerder narratiewe konstruksies van 'n vergange werklikheid is (kyk Lorenz 1987:100). Volgens hierdie historici ontdek 'n historikus ook nie die samehang van so 'n verhaal in die vergange werklikheid nie, maar gee hy of sy eerder self die samehang aan so 'n narratiewe konstruksie van die verlede (Lorenz 1987:100). Die individuele momente van so 'n verhaal van die verlede het hiervolgens ook slegs betekenis in terme van die verhaal as geheel (Lorenz 1987:100). Aangesien die samehang van so 'n verhaal egter die skepping van die historikus is, word die betekenis van gebeure uit die verlede volgens hierdie beskouing dan deur die historikus bepaal.

Die produk van historiese navorsing sou dus volgens die historiese relativisme nie 'n weerspieëling van die vergange werklikheid wees nie, maar eerder 'n weerspieëling van die subjektiwiteit van die historikus. Volgens die relativisme word die betekenis van die vergange werklikheid telkens deur die historikus geskep (Fay 1998:6). Die kriteria waarvolgens sodanige historiese konstruksies geweeg word, is nie meer die mate waarin dit met die stand van sake in die vergange werklikheid kongrueer nie, maar eerder die funksionaliteit daarvan in die hede. Gevolglik is die verskynsel dat die getuienis aangaande die vergange werklikheid nie neutraal en objektief daar uitsien nie, nie vir die historiese relativisme problematies nie. Daar word immers nie hier belang gestel in die vergange werklikheid as sulks nie, maar bloot in historiese konstruksies wat die een of ander waarde of belang in die hede doeltreffend kan dien (Southgate 1996:112-113; vgl Geyser 1999:129-134).

Wanneer hierdie beskouing op historiese Jesus-studies van toepassing gemaak word, kom dit daarop neer dat die getuienis aangaande Jesus se lewe geen konstituerende rol kan speel in die wyse waarop ons die lewe van Jesus uiteindelik beskou nie. Eerder sal die linguïstiese en teoretiese konstruksies wat reeds bestaan, ons beskouinge aangaande Jesus se lewe bepaal. Die benadering van Kähler is vir ons 'n voorbeeld in hierdie verband. Volgens Kähler is dit onmoontlik om enigiets oor die historiese Jesus te weet, 
omrede die evangelies nie geskik is om as bronne vir sulke navorsing te dien nie (Dawes 1999:214). Alhoewel hy hiermee nie doelbewus 'n relativistiese posisie met betrekking tot die historiese Jesus inneem nie, kom sy beskouing tog daarop neer dat die getuienis aangaande die historiese Jesus geen rol kan speel in historici se rekonstruksies van Jesus se lewe nie. En, soos 'n historiese relativis neem hy dan die standpunt in dat gelowiges nie geïnteresseerd is in die historiese lewe van Jesus as sulks nie, maar eerder in die "Reddende Christus" wat in die hede deur die kerk verkondig word (Dawes 1999:215). Die wyse waarop ons Jesus sien, kan volgens hom dus nie gevorm word deur die getuienis aangaande Jesus se historiese lewe nie. Ons beskouing van Jesus word eerder deur die beeld (konstruksie) van Jesus wat in die hede deur die kerk verkondig word, en deur die belange en sentimente van kontemporêre gelowiges, bepaal. Die belydenis van die kerk bepaal hiervolgens ons beeld van Jesus se lewe op aarde, en nie die getuienis aangaande daardie lewe nie.

Die beswaar sou hier geopper kon word dat die kerk se beskouing van Jesus juis deur die getuienis van Jesus se lewe in die evangelies bepaal word, sodat hierdie nie op relativisme sou neerkom nie. As teenvraag sou ons egter kon vra na die wyse waarop die getuienis van Jesus se lewe in hierdie geval gebruik word. Word dit as historiese bronne gebruik, of word dit gebruik om die een of ander metafisiese (a-historiese) Christus te konstrueer? In hierdie verband sou ook gevra kon word waarom alle bronne oor die lewe van Jesus nie hier gebruik word nie (kyk Geyser 1999:77-78).

Craffert (2001:7-8) wys daarop dat Christene altyd die een of ander beeld van Jesus as historiese figuur sal hê, omrede die meeste Christene daarvan uitgaan dat Jesus wel 'n historiese figuur was (kyk o a Earl Doherty [1999] en Robert Price [2000] vir die teendeel). Wanneer hierdie beelde egter nie op grond van 'n wetenskaplike historiese ondersoek van die getuienis aangaande Jesus se lewe geskets word nie, bestaan die gevaar dat die beelde slegs subjektiewe konstruksies van Jesus se lewe volgens die sentimente en belange van gelowiges in die hede kan wees (Craffert 2001:8). In soverre die getuienis aangaande die historiese lewe van Jesus nie as historiese bronne tot hulle reg kom nie, kom hierdie tipe beskouing op 'n relativisme met betrekking tot die geskiedwetenskap neer.

\section{PROBLEME MET RELATIVISME}

'n Belangrike probleem van relativisme is die verskynsel dat hierdie perspektief 'n interne kontradiksie behels. Wanneer die konstituerende aard van linguïstiese en teoretiese konstruksies verabsoluteer word, word dit per implikasie onmoontlik om enigiets oor die stand van sake in die reële 


\section{Objektivisme en relativisme}

werklikheid te weet of te sê. Maar, relativisme behels dan self 'n standpunt met betrekking tot die stand van sake in die reële werklikheid. Dit verteenwoordig naamlik die standpunt dat uitsprake oor die stand van sake in die reële werklikheid onmoontlik sou wees. Daarom ondermyn relativisme sigself wanneer dit as 'n legitieme standpunt ingeneem word (Fay 1998:8). Indien daar voorgehou word dat niks met betrekking tot die historiese Jesus gesê kan word nie, kan laasgenoemde uitspraak (dat niks met betrekking tot die historiese Jesus gesê kan word nie) ook nie gemaak word nie. Ook hierdie uitspraak word immers in verband met die historiese Jesus gemaak.

'n Verdere probleem van relativisme is dat dit deur die praktyk as verkeerd uitgewys word (Bunzl 1997:109). Indien die betekenis van alle empiriese data altyd relatief is tot die bepaalde teoretiese konstruksie van waaruit daardie data beskou word, behoort empiriese data nooit 'n betekenisvolle rol te speel in die beoordeling van opponerende teorieë nie. Maar hierdie is in die praktyk nie die geval nie, omrede dit voor die hand liggend is dat empiriese data wel 'n rol speel in die beoordeling van teorieë (Bunzl 1997:108-109; vgl Lorenz 1987:282).

Volgens Lorenz (1987:282) word empiriese data wel in 'n negatiewe sin ingespan om verskillende teoretiese konstruksies te beoordeel. Empiriese data dui die grense aan waarbinne teorieë ter verklaring daarvan gevorm kan word. Lorenz (1987:37) illustreer hierdie waarheid aan die hand van 'n voorbeeld uit die Astronomie. ${ }^{2}$ Die empiriese waarneming dat die son in die ooste opkom, deur die hemelruim beweeg en dan weer in die weste ondergaan, kan vanuit twee verskillende teoretiese gesigspunte twee uiteenlopende betekenisse aanneem. Wanneer hierdie empiriese waarneming deur die Ptolomeïse bril gemaak word, beteken dit dat die aarde stilstaan en dat die son om die aarde beweeg. Wanneer dieselfde empiriese waarneming egter deur die Galileïse bril gemaak word, beteken dit weer dat die aarde om die aarde se eie as draai terwyl dit om die son beweeg (Lorenz 1987:37). Alhoewel die empiriese waarneming dat die son deur die hemelruim beweeg, in terme van beide bogenoemde teorieë betekenisvolle "feite" kan wees, kan dit egter nie 'n betekenisvolle "feit" wees in 'n teorie wat daarop aanspraak maak dat beide die aarde en die son stilstaan nie.

Sodanige empiriese waarnemings diskrimineer dus wel tussen verskillende teoretiese konstruksies. Alhoewel empiriese data dus nie gebruik kan word om teorieë finaal te bevestig nie, kan dit wel die grense aandui waarbinne legitieme teorieë gevorm kan word. Daar kan nou wel geargumenteer word, dat selfs wanneer 'n brokkie empiriese data die doel dien om 'n bepaalde teorie te ondermyn, dit dan steeds net in terme van daardie teorie betekenis het. Dit het in so 'n geval net betekenis op 'n negatiewe manier.

\footnotetext{
${ }^{2}$ Kyk Lorenz (1987:47-55) vir voorbeelde uit die geskiedwetenskap.
} 
Wanneer die empiriese waarneming dat die son deur die hemelruim beweeg, 'n betekenisvolle feit word wat die teorie ondermyn dat beide die son en aarde stilstaan, is dit steeds net 'n betekenisvolle stukkie data in terme van daardie teorie. Die feit bly egter staan dat empiriese data in sulke gevalle wel betekenisvolle implikasies vir sulke teorieë het, omrede dit die aansien en legitimiteit van daardie teorie beïnvloed.

Ook met betrekking tot die historiese Jesus dui die praktyk daarop, dat die getuienis van Jesus se lewe in die evangelies wel 'n vormende rol speel in die wyse waarop Jesus se lewe in die hede gerekonstrueer word. Craffert (2001:7) wys tereg daarop dat die evangelies wel 'n rol speel in die historiese beeld wat meeste Christene van Jesus het. Op grond van die getuienis aangaande Jesus in die evangelies, konstrueer baie gelowiges 'n beeld van Jesus as goddelike "superhero" wat allerhande probleme en kwale op aarde in 'n japtrap kom regsien het. Die probleem met hierdie tipe rekonstruksies is egter dat dit naïef daar uitsien, omrede daar nie erns gemaak word met die problematiek van die historiese navorsingsproses nie (Craffert 2001:8). Die nodige stappe word nie gedoen om te verseker dat die getuienis aangaande Jesus se lewe tot hulle reg kom nie, sodat die getuienis ook nie die geleentheid kry om korrigerend op hierdie konstruksies van Jesus se lewe in te werk nie.

\section{OBJEKTIVISME, RELATIVISME EN KONTEMPORÊRE JESUS-STUDIES}

In hierdie afdeling kyk ons kortliks na die wyse waarop objektivisme en relativisme in twee onlangse Suid-Afrikaanse voorstelle met betrekking tot historiese Jesus-studies na vore kom. Die doel is om aan te toon dat hierdie wetenskap-filosofiese konseptualisering van die problematiek rondom historiese Jesus-studies 'n nuttige middel is in die kritiese nadenke oor historiese Jesusstudies. Dit kan ons onder andere help om onnodige probleme te voorkom.

Seccombe (1999:525-548) pleit vir 'n kanonieke benadering tot Jesusstudies. Volgens Seccombe kan die evangelies, op grond van hulle kanonieke gesag, as betroubare bronne vir 'n rekonstruksie van Jesus se lewe gebruik word. Seccombe hou egter nie rekening met die verskil tussen enersyds die gesag van die evangelies vir die kerklike leer en lewe en, andersyds, die gesag van die evangelies as bronne vir historiese navorsing nie. Dit is nie vanselfsprekend dat die kerk en die historikus die evangelies op dieselfde wyse móét benader nie. Die implikasie van Seccombe se standpunt is dus dat die evangelies nie as bronne vir historiese navorsing sou dien nie. Verder sou Seccombe se voorstel ook daarop neerkom dat buite-Bybelse bronne vir historiese Jesus-studies, soos die evangelie van Thomas, misken word. Seccombe se voorstel kom dus op 'n relativisme neer, omdat die getuienis van 


\section{Objektivisme en relativisme}

en oor Jesus as historiese figuur nie in Seccombe se voorstel tot hulle reg sou kom as data vir historiese navorsing nie.

Craffert (2001:1-27) argumenteer weer vir 'n "kultuur-sensitiewe" benadering. Volgens hierdie voorstel behoort die doel van historiese navorsing nie te wees om die lewe van Jesus te rekonstrueer nie, maar om die tipe persoon wat Jesus was, vas te stel deur 'n studie van die wyse waarop hy in die bronne beskryf word. Deur te let op die tipiese wyse waarop mense in die Mediterreense kultuur van die eerste eeu getipeer is, kan ons iets wys word van die wyse waarop Jesus se lewe binne daardie kultuur verstaan is. Indien Craffert nie hier 'n objektiewe beeld van Jesus as historiese figuur in gedagte het nie, sou die implikasie wees dat die motivering vir hierdie tipe kennis van Jesus nie bloot die waarheid aangaande Jesus op sigself sou kon wees nie. Craffert noem die tipe kennis wat hy in gedagte het, "nuttige kennis" maar hy brei nie uit oor die belange wat die ondersoeker in die hede by die daarstel van sodanige kennis het nie. Dit wil dus voorkom asof Craffert wel objektiewe kennis van Jesus as historiese figuur in gedagte het, met die implikasie dat sy voorstel op 'n objektivisme sou neerkom.

Hierdie wetenskap-filosofiese perspektief op Craffert en Seccombe se onderskeie voorstelle, stel ons nie maar net daartoe in staat om etikette rondom hulle nekke te hang nie. Dit maak ons eerder bewus van die belangrikheid van die wetenskap-filosofiese perspektief op historiese Jesus-studies. Die minste wat ons in elk geval sou kon sê, is dat Craffert en Seccombe nie voldoende die wetenskap-filosofiese aspekte van hulle onderwerp oorweeg het nie. Indien hierdie outeurs wel die wetenskap-filosofiese problematiek ernstig opgeneem het, sou hulle ten minste probeer het om die probleme rondom objektivisme en relativisme in hulle voorstelle te oorkom.

\section{SAMEVATTING}

Om in terme van objektivisme en relativisme oor die geskiedwetenskap te praat, blyk in retrospek wel 'n legitieme perspektief op hierdie saak te wees. Vele teoretici van geskiedenis as wetenskap praat in elk geval in terme van hierdie opponerende perspektiewe oor historiese navorsing. Verder het ons ook aangetoon hoe hierdie problematiek in kontemporêre Jesus-studies in Suid-Afrika na vore kom. Alhoewel dit sekerlik nie die enigste moontlike manier is waarop ons die teorie van die geskiedwetenskap, oor die algemeen, en historiese Jesus-studies, in besonder, kan benader nie, bied dit wel 'n invalshoek waarmee ons verder kan werk. Deur die wetenskap-filosofiese problematiek rondom historiese Jesus-studies in terme van "objektivisme" en "relativisme" te konseptualiseer, kry ons immers 'n aanduiding van daardie perspektiewe op historiese Jesus-studies wat nie werk nie. Dit dring ons ook 
daartoe om opnuut na te dink oor die fundamentele vooronderstellinge van historiese navorsing en historiese Jesus-studies. Verder wys hierdie perspektief ons op die belangrikheid daarvan om in historiese Jesus-studies op 'n eksplisiete wyse verby die Cartesiaanse denkraamwerk wat tot objektivisme en relativisme aanleiding gee te beweeg.

\section{Literatuurverwysings}

Bernstein, R J 1983. Beyond objectivism and relativism: Science, hermeneutics and praxis. London: Basil Blackwell.

Bunzl, M 1997. Real history: Reflections on historical practice. London: Routledge.

Craffert, P F 2001. Vernuwing in historiese Jesus-navorsing. Verbum et Ecclesia 22(1), 1-28.

Dawes, G W 1999. The historical Jesus quest: Landmarks in the search for the Jesus of history. Leiderdorp: Deo Publishing.

Descartes, R 1911a. Meditations on first philosophy, in The philosophical works of Descartes, vol 1, tr by E S Haldane \& G R T Ross. Cambridge: Cambridge University Press.

Descartes, R 1911b. The principles of philosophy, in The philosophical works of Descartes, vol 1, tr by E S Haldane \& G R T Ross. Cambridge: Cambridge University Press.

Doherty, E 1999. The Jesus puzzle: Did Christianity begin with a mythical Christ? Ottawa, Canada: Canadian Humanist Publications.

Dreyer, P S 1974. Inleiding tot die filosofie van die geskiedenis. Kaapstad: HAUM.

Fay, B 1998. Introduction, in Fay, B, Popper, P \& Vann, R T (eds), History and theory: Contemporary readings, 1-11. New York: Blackwell Publishers.

Gadamer, H 1985. The historicity of understanding, in Mueller-Vollmer, K (ed), The hermeneutics reader: Texts of the German tradition from the Enlightenment to the present, 256-292. London: Basil Blackwell.

Gadamer, H 2003. Truth and Method. 2nd revised edition, tr by J Weinsheimer \& D G Marshall. New York: Continuum.

Geyser, P A 1999. Die hermeneutiese uitgangspunte in die "nuwe historiese benadering" tot Jesus-studies. DD-proefskrif, Universiteit van Pretoria.

Grondin, J 1994. Introduction to philosophical hermeneutics, tr by J Weinsheimer. New Haven, CN: Yale University Press.

Heidegger, M 1935. Sein und Zeit. Unveränderte 4. Aufl. Halle: Max Niemeyer, Verlag.

Jenkins, K 1991. Re-thinking history. London: Routledge.

Kähler, M [1896] 1969. Der sogenannte historische Jesus und der geschichtliche, biblische Christus. Neu herausgegeben von E Wolf. 4.Auflage. München: Kaiser Verlag. (TB Band 2, Systematische Theologie.)

Lorenz, C 1987. De constructie van het verleden: Een inleiding in de theorie van de geschiedenis. Amsterdam: Boomappel.

Price, R M 2000. Deconstructing Jesus. Amherst, NY: Prometheus Books.

Romm, N 1987. Habermas se wetenskapsteorie, in Snyman, J J \& Du Plessis G W (reds), Wetenskapbeelde in die geesteswetenskappe, 181-194. Pretoria: RGN. 


\section{Objektivisme en relativisme}

Seccombe, D 1999. Wanted: A new approach to the life of Jesus. In die Skriflig, 33(3), 525-548.

Spangenberg, I J J 2004. Om oor God te praat: 'n Kritiese oorsig van gesprekke onder Afrikaans-sprekende Christene van die gereformeerde tradisie (19982003). Verbum et Ecclesia 25(1), 274-293.

Southgate, B 1996. History: What \& why? - ancient, modern and postmodern perspectives. London: Routledge.

Van Aarde, A G 2004. Postmoderne epistemologie en postkoloniale hermeneutiek. HTS 60(3), 1105-1125.

Via, D O 2002. What is New Testament theology? Minneapolis, MN: Fortress Press.

Weiten, W 2001. Psychology: Themes and variations. Stamford: Wadsworth. 